\title{
CERN officials visit Tokyo, hat in hand, in search of funds for their next big collider
}

Tokyo. These days, all roads to expensive high-energy physics projects seem to go through Japan.

Officials from the European Laboratory for Particle Physics (CERN) turned up last week in their first-ever attempt to woo the Japanese. What they were selling is a piece of the laboratory's next big collider project, the Large Hadron Collider (LHC), which they hope to turn on before the end of the decade. Walter Hoogland, director of research at CERN, and James Allaby, leader of CERN's experimental physics division, toured all of Japan's science-related ministries and agencies as part of a campaign to find outside support for the $\$ 1,500$-million machine.

The visit comes in the midst of a determined effort by US officials to persuade the Japanese to help pay for their next big machine, the $\$ 8,500$-million Superconducting Super Collider (SSC), also scheduled to begin work in 1999. Earlier this year, the United States and Japan formed a Joint Working Group to discuss Japan's contribution to the proton-antiproton accelerator, and SSC officials are confident (see story below) that they have the inside track on whatever money the Japanese decide to spend on high-energy physics projects beyond their shores.

Hoogland and Allaby did not specifically ask the Japanese for financial support to build the LHC. That is most likely to happen in August, when Carlo Rubbia, CERN's director general, visits Tokyo. But Japan has a limited amount of money for such international collaborations, and it probably cannot afford to make a significant contribution to both machines.

The CERN officials and European embassy officials in Tokyo deny that they are competing with the SSC laboratory for Japanese funds. The two projects, they say, are "complementary". But in their discussions with the Japanese they made no secret of the advantages they think the LHC and CERN hold over the SSC.

Speaking at a reception at the British Embassy, Hoogland pointed out that CERN projects are less expensive because they use existing accelerators as a "stepping stone" to the next machine. In the case of the LHC, that means using the tunnel built for the Large Electron-Positron (LEP) accelerator. The European collider, he points out, can draw upon a well-tested infrastructure and an experienced technical staff, whereas the

\section{SSC says it holds the edge}

Washington. Roy Schwitters, director of the Superconducting Super Collider (SSC) laboratory, believes that the United States has built up the sort of diplomatic ties with Japan that are needed to win any financial commitment from the Japanese for the proton-antiproton collider. That is not true for his European colleagues from CERN, he says, who are hoping that the Japanese will also help pay for the laboratory's proposed Large Hadron Collider.

"You shouldn't underestimate the value of the Joint Working Group that we have established", says Schwitters, referring to the administrative arrangement created in January when the US president, George Bush, met the Japanese prime minister, Kiichi Miyazawa, in Tokyo. "The Japanese put great weight behind the existence of that group. To them, it signifies how committed they already are to the project." The group met in Tokyo for the first time in April, and has formed panels that will study specific issues and report back to the working group in the autumn.

The delegation from CERN, on the other hand, has no official status in Japan, Schwitters points out. And without it, he says, it is all but impossible to turn even the best intentions of scientists and bureaucrats into hard cash.

"Carlo Rubbia [CERN's director general] is a very respected senior scientist, but he doesn't have the benefit of our formal relationship", says Schwitters. "And believe me, that makes a big difference."

Meanwhile, Schwitters has problems of his own in shepherding the SSC through the US political process. Last week, for example, the energy and water appropriations subcommittee in the US House of Representatives slashed the president's 1993 request for $\$ 650$ million for the SSC, recommending instead that the laboratory receive only its current budget of $\$ 484$ million.

"That will mean delays", says Schwitters about the first of several congressional votes this summer on the project. "It's very hard to ramp up a project when you don't get what you need. In effect, level funding would force us to start cutting back just when we should be moving forward." Jeffrey Mervis

SSChas to be built and tested "from scratch". CERN, with 17 members, also has much more experience with large international collaborations, the Europeans add.

Those officials say that it is because of the international character of CERN that they are now knocking on Japan's door. In the past few years, the number of Japanese scientists using CERN's facilities has grown to 70 , compared with only a dozen in 1982. This presence is comparable to the number of users from the Netherlands, which is a member of CERN. But, unlike the Netherlands, Japan pays nothing for this access, and CERN officials feel the time has come for some financial contribution.

CERN hopes that non-member nations that use CERN's facilities will contribute roughly 20 per cent, or about $\$ 300$ million, of the cost of building the LHC. The US Department of Energy has promised Congress that one-third of the initial cost of the SSC, or about $\$ 2,800$ million, will come from non-federal sources; Texas has already pledged $\$ 1,000$ million, leaving some $\$ 1,800$ million to come from the rest of the world.

It is too early to predict how the Japanese will respond to CERN's entreaties. An official at the Ministry of International Trade and Industry (MITI) who met Hoogland and Allaby says that "we don't think about the LHC, only the SSC". However, a foreign ministry official says that "both projects have merit" and that the Japanese government will consult Japanese scientists for advice.

Many Japanese high-energy physicists say that the decision on whether to contribute to the SSC has become a matter of politics, not science. The decision will be up to Kiichi Miyazawa, the prime minister, who has been under considerable pressure from the US president, George Bush.

Although no one pretends to know what Miyazawa will do, one official from Japan's Science and Technology Agency says that the timing of the European approach is "very good". The Japanese cabinet, in line with numerous recommendations from government committees, recently called for a doubling of the government budget for science. But it did not specify a timeframe. A vigorous debate is now going on between the Ministry of Finance and a science pressure group within the ruling Liberal Democratic Party on when and how to implement the increases. Most of the extra money is expected to go to domestic research, but some may be available for international programmes.

David Swinbanks 